\title{
The Waala Chieftaincy Institution: Its Origin and the Emergence of Disputes
}

\author{
Hafiz Bin Salih ${ }^{1}$ \\ 1 Wa Municipal Education Office, Ghana Education Service, Wa, Upper West Region, Ghana \\ Correspondence: Hafiz Bin Salih, PhD, Wa Municipal Education Office, Ghana Education Service, Wa, Upper \\ West Region, Ghana. Tel: 2332-0825-6850.
}

Received: June 20, 2018

Accepted: July 2, 2018

Online Published: July 23, 2018

doi:10.20849/ajsss.v3i3.426

URL: https://doi.org/10.20849/ajsss.v3i3.426

\begin{abstract}
The purpose of the research paper was to trace the origin of chieftaincy among the Waala of the Upper West Region of Ghana as well as discuss the emergence of the Wa chieftaincy conflict. The Waala monarchy and the Wa Naa are the custodians of Waala customs and culture which provide transparent processes for the choice of a new Wa Naa and other leaders and for any conflicts arising thereof. Chieftaincy disputes tend to be overlooked by the authorities expected to resolve them; probably because they perceive such conflicts as tractable and not complex. There are provisions within Waala society and in the Kingdom for indigenous means of dispute resolution that have been relegated to the background. The origin of chieftaincy among the Waala has been traced while the perceived causes of the Wa chieftaincy conflict has been discussed. This research paper is part of my $\mathrm{PhD}$ thesis that was submitted to the university but has not been published.
\end{abstract}

Keywords: chieftaincy, conflict, conflict resolution

\section{Introduction}

Chieftaincy institution has been in existence in Ghana for hundreds of years; serving a crucial role in the country's traditional governance and socio-cultural systems. Chieftaincy institution is held in high esteem. It is deemed to be an embodiment of the spirit of a people as chiefs are deemed to intermediate between the living and the ancestors. The chieftaincy institution also provides a sense of identity and belongingness. The chief is not only seen as the symbol for allegiance, but also a powerful pillar for social cohesion and harmony. The centrality of the role of the chief in the traditional social structure impels Assimeng (1999:181) to describe the chieftain institution in the country as the 'bedrock of the social structure of Ghana and chiefs are seen as the repository of culture.' This said, it should, nonetheless, be said that Ghana's chieftaincy systems have a varied history and the character they manifest are very much the reflections of the worldview of the people and their culture.

Chieftaincy system in the traditional governance structure is hierarchical in nature. The individual wielding the highest traditional authority is referred to as the paramount chief. Examples in some Ghanaian traditional jurisdictions include: Omanhene (Akan), Fiaga (Ewe) and Yagbonwura (Gonja) and Wanaa (Wala). In the discharge of his duties the paramount chief is supported by subordinate traditional authorities known as divisional chiefs, and the scale of authority goes further down through family heads to the ordinary subject. In every Ghanaian town there is a traditional authority (chief) who goes by such titles like Naa, Odikro, Ohene, Kuoro, Togbe, etc, (meaning 'Chief' in different local languages). This, thereby, creates a situation where practically every member of the Ghanaian society would at some point become deferent to a 'stool' or 'skin' that symbolises traditional authority (Assimeng, 1999).

In fact, pre-colonial Ghanaian societies were characterised by two main types of the traditional governance systems. The non-centralised 'acephalous societies' repreents one of the two genres. Typical ethnic groups associated with this genre include the Talensi, Dagaaba, Lobi, and Konkomba (Tuurey, 1982: 38). In all of these acephalous societies, the political ultimate authority rested with the head of each family. Centralised, hierarchical states as it is found among some southern Ghana's ethnic groups like the Akans' and northern Ghana's Nanumba, Maprusi, Dagomba, Wala and Gonja (Nabila, 2006:4) represented the second form of traditional governance. In this system, traditional authority was held by the chief (Tuurey, 1982:38). While most writers on the history of northern Ghana have always asserted that the only centralized states were those of Mamprugu, Dagbon, Nanum, 
Gonja and Wala, Tuurey (1982) pointed out that others such as Manlarla of Kaleo and Wecheau based at Dorimon also existed even if they did not form large empires. Chieftaincy in the Waala society has always been centralised and that was why the British colonial administration had to depend on it to have unfettered access to the then north-west province in the colonial era.

It is based on the recognition of the important roles chiefs have played in the governance system from the pre-colonial period to the current postcolonial dispensation that the architects of the 1992 Constitution decided to guarantee the chieftaincy institution in Article 270 (1). It assigns the chieftaincy institution itself the role to retain peace and harmony within its ranks through the expression of appropriate laws. Within the contemporary governence system, traditional leaders are made to play roles that straddle both the political and social spectrum in community and national arenas. While the chief continues to undertake his traditional responsiblities, he also acts as the most important interface between his subjects and the central government.

\subsection{Statement of the Problem}

This research paper is to trace the origin of chieftaincy among the Waala of the Upper West Region in Ghana. Also, the research paper shall discuss the perceived causes and emergence of the Wa chieftaincy conflict.

\section{Research Questions}

The following specific research questions are posed to guide the work:

1. What are the origins of the Wa chieftaincy conflict?

2. What are the perceived causes of the Wa chieftaincy conflict?

\section{Research Method}

The mixed method approach was used for the research. The combination of qualitative and quantitative approaches in data collection and analysis is accepted in social sciences.

\subsection{Identification and Selection of Study Sites, Study Population and Sample Size}

The research explored the experiences of some people residing within the four divisional gates of the Waala paramountcy: Busa, Guli, Kperisi and Sing. The target sample for this study were chiefs, local opinion leaders and, officials of the Regional House of Chiefs, the Waala Traditional Council, the Wa Municipal Assembly and the Wa Municipal Command of the Ghana Police Service, the Tendaana, the Chief Imam and the Yari-naa. In addition, members of the general populace of the territory of the Waala paramountcy were included in the sample. A sample size of 139 respondents was used for the research.

\subsection{Data Collection Methods}

There are two forms of data in social research: primary data and secondary data (Miller, 1991). Therefore, both primary and secondary data were used in this research. Participants for the primary data collection were identified using purposive and quota sampling strategies. This included members of the four legitimate gates of the Wa skin, along with members of all relevant organisations and groups who are actively involved in the Waala chieftaincy conflict. In total, fifteen (15) respondents were purposely selected and they took part in the semi-structured interview. To complement these individual interviews, four (4) focus group discussions were held in Wa. The eight (8) participants in each of the focus group discussion sessions were selected by their respective head of royal gate. The researcher had to depend on the heads of the royal gates because, matters of chieftaincy are very sensitive and a lot of people do not often want to discuss it. Four communities - Busa, Guli, Kperisi and Sing - were selected for inclusion because they are the legitimate divisional seats of the Wa paramountcy. A total of 139 respondents participated in the research survey.

\section{Discussion of Findings}

\subsection{The Waala Chieftaincy Institution, Its Origin and the Emergence of Disputes.}

The term Waala refers to the natives of Wa in the Upper West Region of Ghana. Like many other ethnic groups in Ghana, Waala are people from diverse backgrounds who as a result of living together for long and being guided by some culture and a traditional political unit have bonded and have become a unit. In the words of Wilks (1982:16), "people may identify themselves, or be observed by observers in one context by reference to historical origins, in another to language and culture, and to yet another to traditional political affiliation." To Wilks (1982), "the Wala were those who not only recognised the authority of the Wa Nas but who identified with the whole system of governance of which the Wa Nas were themselves a part." According to Nabikpong of Busa, Waala refers to "the people whose origin can be traced to these four segments of Wa; Tendaamba, Nabihi, 
Limanhi, and Yarihi." In the same vein, Bin Salih (2001) is of the opinion that "the term Wala means people of Wa. In other words, it is a reference to those who are natives of Wa".

This research paper has revealed that Waala is made up of Tendaamba (they are of Lobi origin), Nabihi (they are of Manprugu origin), and the Limanhi and the Yarihi (they are both of Mandeka origin). According to Bin Salih (2001), of the three traditional estates of Waala, the Nabihi are at the top of the kingdom, the Yarihi constitute the other estate, and the Tendaamba are at the bottom.

According to a key informant "Over the years, there has been much focus on finding out exactly how the Naang (chieftain) of the Waala originally developed. In fact, contemporary explanations and answers have been provided in the form of early studies, interview transcripts, and focus group sessions. From this evidence, it is now clear that the Naang of the Waala was not a side branch of the Naang of the Mamprusi. It is also known that the very first Naa (chief) of Wa was named Soalia. He was a royal from Mamprusi, but he relocated to Wa from Nalerigu" (an interview with a key informant on $2^{\text {nd }}$ May, 2016). This does not mean, as might be thought, that Wa belonged to the Mamprusi. Prince Soalia only arrived in Wa during the $17^{\text {th }}$ century. His position and status were, initially, a traveller. However, with the help of the Tendaana of Wa and the Muslim cleric, Yamuori, he ended up establishing the Waala chieftaincy as an autonomous domain. Hence, it is true to say that the Naang of Wa originated from Wa, by the Waala. When Soalia travelled to Wa, he arrived as a Nabia of Mamprugu (a Prince of Maprugu), rather than as a Na of Wa (Daanaa, 1992). The point to remember is that the "Wa-Naang is not an extension of the Naang of Mamprugu, except that the first Wa Na traces his roots to Maprugu. It should also be noted that, as Soalia was already of Mamprugu royalty, there was a clear blood tie between the Naang of the Mamprusi area and the Naang of the Waala" (an interview with a key informant, $2^{\text {nd }}$ May, 2016). To begin with, when Naang was first introduced as a source of influence and power in Wa, the area was controlled by just a single, unified royal clan. There were no conflicts or questions over the issue; nor were there any attempts to split power between different family groups (or gates). As the years progressed, these circumstances gradually changed. In the words of a key informant, by the close of the $18^{\text {th }}$ century, the ruling clan in Wa witnessed both conflicts and gates. These gates or ruling sections - were each given a title. There were four in total; Jarri, Kpaaha, Yijihi, and Joyonhi (an interview with a key informant on $2^{\text {nd }}$ May, 2016). The four gates were named after influential Naa figures who had established them. According to a key informant, "Jarri, Joyonhi, and Yijihi were the male heirs of Naa-Pelpuo I. He controlled Wa at about the close of the $17^{\text {th }}$ century. After he died, his oldest child, Yijihi, was made Naa and established the Yijihi gate. Once he died, his younger brother Jarri assumed responsibility. He also created a gate and named it after himself. The last of the three children, Joyonhi, came to power when it was his turn and did the same. The final gate was established by Kpaaha, who was not the son of Pelpuo. Instead, he was a paternal cousin of the three sons" (an interview with a key stakeholder, $2^{\text {nd }}$ May 2016). This last ruler came into power at the start of the $18^{\text {th }}$ century. As expected, every gate consists of the descendants of the man who created it. They are, in many respects, separate royal domains of a larger realm. This means that all four gates of the Nabihi (princes) were given special privileges and powers. For example, they had the opportunity to appoint Namine (chiefs) for a number of villages inside their territory. This is why the Jarri gate gave successors to the skins of Dzonga, Kperesi, and Yeru. The Joyonhi gate did the same for Chansa, Sing, and Boli. The successors to the Kpaaha gate include Konjihi, Nyagili, and Guli. And, finally, the successors for Tampala, Busa, and Nakora are from the Yijihi gate. If a section or faction was ruled by a good Naa, with the strength and skill to capture many enemy territories, all newly acquired areas would be passed on to his sons when he died (Wilks, 1989; 1999). This could be a reason why the gates of Joyonhi, Yihiji, and Jarra are much closer, geographically than the last gate of Kpaaha. One of the most compelling explanations for the transition between a single, unified ruling entity and a series of separate gates is that the separate factions developed as the royal family expanded and became harder to control with just one ruling family (an interview with a key informant, 2nd May, 2016). However, there is still a lot of mystery surrounding this change. All of the reasons why it happened are not yet clear or fully understood, even though researchers are keen to find out.

\subsection{Nature of the Traditional Political System of the Waala}

The Wa Naa serves as the ultimate traditional authority over the numerous Waala ethnic groups and clans under the traditional Waala system. Traditionally, "Waala chieftaincy system is in layers with the position of Wa Naa at the apex" (an interview with a key informant, $2^{\text {nd }}$ May, 2016)). Divisional chiefs, such as those serving Gulli, Busa, Kperihi and Sing, are appointed authorities under the Wa Naa. Beneath these divisional chiefs are the lower chiefs, appointed as junior chiefs down to the least rank. All junior, lower and divisional chiefs ultimately aim at an eventual succession to the Wa Paramountcy. Under the traditional system, the highest position is that of the Wa Naalung. As an example, the Joyonhi royal gate's last station before ascending to the Wa paramountcy is the Sing Divisional Headquarters, with Boli, Chansa, Loggu, Jayiri and Chasia as subdivisions. Therefore, "Joyonhi chiefs 
begin their positions at Chasia and rise through the ranks to Jayiri, Loggu, Chansa, and so on. Once chiefs reach Sing, they are well positioned to occupy the Wa Naalung" (FGD, $1^{\text {st }}$ May, 2016). It is certain that the establishment of these promotional stations was designed as a mentorship system. Here, a prince could achieve the status, experience, and the knowledge necessary for succession to the Wa Naang. However, this does not mean that the Wa Naang could only be reached through strict adherence to this promotional system: appointments were also made as per the needs of the group and according to the circumstance. Ivor Wilks explained that "In 1948, the princes of Sing decided that they wished to make a strong bid for the Wa Naalung when it next became vacant. They recognised, however, that the Sing Naa Saaliya would not command strong support either within the other segments of the princely estate or the other estates. Their choice instead fell upon Moomin Koray, a grandson of Wa Naa Tanhunaa (1906-1919) and a man of strong character in 1948. Saaliya abdicated from the Sing skin on the grounds of ill-health, and Moomin Koray was elected to it. On the death of Wa Naa Sumaila in 1949, Moomin Koray was elected Wa Naa" (Wilks, 1989:358).

It should be noted that, "unlike Joyonhi, the remaining three gates have no established structure, although the Yijihi gate does possess the Busa, Nakori, Dussie and Katua stations, Jarri holds the Kperihi, Degu, Chegli, Jonga, Yibile and Yaru stations, and Kpaaha holds the Gulli, Siiru and Konjierhi stations" (an Interview with a key informant, $15^{\text {th }}$ May, 2016). Thus, village-level sub-divisional chiefdoms are at the lower rank of the centralised Waala hierarchical system. Ultimately, the Wa Naa has the final say in the succession of every sub-divisional and divisional chief.

According to a key informant "the Waala Kingdom's Paramount Chief and head is the Wa Naa, who is supported by four divisional chiefs who serve as heads of the four rightful gates. They are also supported by numerous sub-divisional chiefs. There are some chiefs who (for instance, Kundugu Naa, Funsi Naa, Kojokperi Naa, Manwe Naa, Bulenga Naa, Zingu Naa, and Charia Naa) report directly to the Wa Naa but have no formal interaction or association with any of the four rightful gates to the Wa skin. Of these chiefs, none has the right of succession to the Wa skin" (an interview with a key informant, $15^{\text {th }}$ May, 2016).

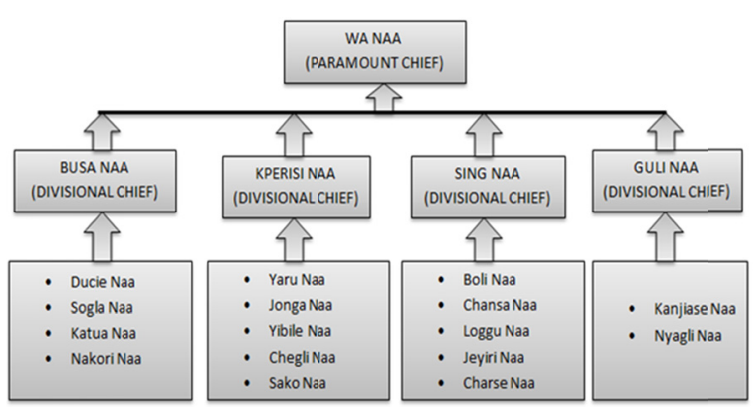

Figure 1. Hierarchy of chiefs in the Waala Kingdom

Source: Researcher's Construct, (2016)

\subsection{Role of the Wa Naa}

From the various Focus Group Discussions, it was found out that, unity within Waala society is represented by the Wa Naa in his role as the primary traditional authority over the Waala Kingdom and as a medium of societal collaboration, togetherness and harmony. Indeed, Waala society moves and grows around the influence of the Wa Naa. The Wa Naa is tasked not only with the Waala kingdom's military administration, but also with the Kingdom's civil administration. Private disputes are raised with the Wa Naa as adjudicator in conflict cases, such as disputes between clans and the violation of Waala customs and norms. A participant in one of the sessions of the FGDs indicated that "The Wa Naa is indeed the key dispute adjudicator for the Waala Kingdom with adjudicative and judicial powers. As a consequence of this power, the Wa Naa functions as the paramount head of the state. This means that he is also in charge of creating and presenting new laws" ( participant, FGD, $4^{\text {th }}$ May, 2016)

The Wa Naa also serves as a host to all of the kingdom's official visitors and appoints from within the Elders-in-Council, a Samba Naa (Hospitality Chief) who reports directly to him on hospitality-related affairs to aid him in his pursuit of humanitarian and state interests. 
The protection of human rights is something for which the Wa Naa has a duty. Thus, the Wa Naa also serves as the judge and head of a court that deals with cases of oppression, injury and other human rights issues. In addition, the Wa Naa is also involved in carrying out proceedings to appeal cases presented by clans and divisions through his court.

The Wa Naa has the ultimate traditional authority over all issues within the Waala Kingdom, and his Eldersin-Council exists to offer consultation, guidance and support. The Wa Naa, as head of state, is also tasked with approving the appointment of divisional and sub-divisional chiefs.

Alongside the Wa Naa's various duties, "the Wa Naa is also granted special power and benefits. For instance, he is to be given the utmost respect and reverence by everyone in the Kingdom, although his personal nature and characteristics will have a significant impact on his popularity and the respect he demands. For instance, if the Wa Naa unduly takes advantage of his power or has his authority challenged by another, he risks an erosion in recognition, status and even position he holds" (an interview with key informant, $2^{\text {nd }}$ May, 2016). The Wa Naa must command respect since he is responsible for creating and maintaining societal order. While the Wa Naa may be involved in handing out penalties in the form of cautions or fines, he may also be required to expel individuals from the Kingdom.

In most cases, the Wa Naa is perceived to represent and hold all of the Kingdom's wealth. Thus, the Wa Naa has the authority to insist upon royalties from any legitimate source. Furthermore, the Wa Naa runs a farm manned by his subjects to keep livestock and other animals that have no owners.

\subsection{The Kpambiihi (Council of Linguists)}

It was also established from data collected that, under the traditional governance system, the Wa Naa takes the position at the top of the chain of authority, aided by the Kpambiihi (Council of Linguists). Members of the Council of Linguists speak for all the key Waala groups and are selected after much consideration. The purpose of the Council is "to uphold their group's interests in the Wa Naa's court. The Council, along with the divisional chiefs, are responsible for ensuring societal harmony while also ensuring that the Wa Naa can make sound decisions on crucial issues" (an interview with key informant, $4^{\text {th }}$ May, 2016). The Kpambiihi is comprised of the following key positions:

\subsubsection{The Widaana}

The Widaana is the primary Kpangbier (Linguist) serving the Wa Naa's court as a spokesperson for the Wa Naa. In the case of state protocol, "the Widaana serves as a chief linguist, mediator and informant, in addition to aiding the Wa Naa's decision-making in court rulings and assisting in discussions between the Wa Naa and his divisional and sub-divisional chiefs. Also, the Widaana is responsible for ensuring that the Wa Naa is celebrated and honoured by praise singers every Monday and Friday. The Widaana also serves as an advisor on issues relating to spiritual matters, purifications, sacred land and the gods" (an interview with key informant, $4^{\text {th }}$ May, 2016).

\subsubsection{The Foroko}

The Foroko upholds the interests of the Tuomune people and serves as a go-between for those hoping to speak with the Wa Naa and the Wa Naa himself. The Foroko also serves as a Master of Ceremony at each Wa Naa's enrobing and enskinment ceremony. He also has a seat during state matters.

\subsubsection{The Four Most Senior Princes}

The four most senior princes (Nabikpong) of the four royal gates of Jarri, Jonyonsi, Kpaaha and Yijiihi are senior members of the Wa Naa's council. These four princes represent their respective gates and, therefore, try to project their interest in the Wa Naa's Palace.

\subsubsection{The Yari Naa}

The Yari Naa serves the Wa Liman and Wa Naa as a chief liaison officer. He also speaks for both non-Nabihi and non-Tendaamba Muslims.

\subsubsection{The Samba Naa (Hospitality Chief)}

The Samba Naa is one of the Wa Naa's Kpambiers, assigned with the task of taking care of guest-related matters. The word 'Samba' refers to the communities within the larger Waala community who moved to Wa following its formation as a state: the Kpaniinayiri, Bangkunyeliyiri, Nupayiri, Jabogu, Saamune, Jengbeyiri and the Zongo. In many cases, the Saamba Naa's office is filled by a member of the Bangunyeliyiri who speaks for the Samba community (meaning those who moved to Wa after its formation as a state). 


\subsubsection{The Wuriche}

The Wuriche is the most senior princess, who serves as an ex-officio Council of Linguistics member and thus, has a major influence on issues related to the Waala Kingdom. The Wuriche essentially plays the role of a Queen Mother in the Kingdom, socially and spiritually recognised as a position of high status. The Wuriche has the primary authority over official proceedings and ceremonies during major events such as the passing away of the Wa Naa. At the Wa Naa's funeral, the Wuriche takes the Tendamba around the body as a declaration and confirmation of the Wa Naa's death. Additionally, the Wuriche is responsible for ensuring that the late Wa Namine's widows are looked after during the performance of the funeral rites.

\subsubsection{The Salanga}

The Salanga serves as a spokesperson for the Daanku people (the Gonja community who moved to Daanku from Kiape following the Gonja-Waala war). The Salanga primarily protects the Wa Naa and the state from any risk or threat. It is said that the Salanga is the person with the greatest insight into the Wa Naa's private life. He is also responsible for monitoring the Wa Naa's wives. The Salanga is provided with substantial remuneration by the Wa Naa for his devotion and confidentiality. During the Wa Naa's lifetime, the Salanga serves as custodian of all property belonging to the skin. However, with the passing on of the Wa Naa, the Salanga transfers guardianship of the skin's property to the Tandaga Naa.

\subsubsection{The Tandaga Naa}

A member of the Kpaahayiri is assigned the role of Tandaga Naa, who serves as the Wa Naa's heir after the passing on of a Wa Naa. Regency is held by one of the Tandaga Naviri members rather than by the princes, under traditional Waala custom. No chiefly power is assigned to this regent status. The Tandaga Naa is responsible for looking after the palace pending the election and enskinment of a new Wa Naa. Additionally, the Tandaga Naa is tasked with the official greeting of visitors. The Tandaga Naa also serves as the palace official to contact for those wishing to visit the Wa Naa's grave after his burial.

It should be mentioned that according to Waala culture, there is no place for regency amongst the princes. Thus, the British Colonial Administration committed one of their worst offences against the Waala people by promoting this idea in the 1933 Waala constitution.

\section{Roll Call of Wa Namine (Chiefs)}

Mallam Issaka (cited in Bin Salih, 2009:69) reports that Sorlea (Soalia) was the first Waala chief, appointed in 1625 with the support of Tendamba head, Suri (Dougah, 1966:115). Although Dougah (1966) and Mallam Issaka (cited in Bin Salih, 2009:69) both report that the first Wa Naa was indeed Sorlea, Wilks (1989:81) argues that Suri was the very first chief of Wa. According to information gathered from the FGDs and key informants, this was not possible, because the Tendaaba did not recognise the chieftaincy system at the time, and "therefore Suri could not have been a chief: instead, he was the leader of the Tendaaba of present day Wa" (interview with Kolkpong Naa Abu Salia on $1^{\text {st }}$ May 2016). The following table outlines, Wa Namine (Wa Chiefs), along with an estimated period of their tenure. It should, however, be noted that the period of tenure of Wa Naa Mahama Fua (1880-1888) to present day, as depicted in the table below, are accurate.

Table 1. List of Wa Namine (Chiefs)

\begin{tabular}{llll}
\hline S/N & NAME & GATE & YEAR \\
\hline 1 & Saliya (Soalia) & & $1625-1656$ \\
\hline 3 & Gura & Yijihi/Kpaaha & $1675-1681$ \\
\hline 4 & Pelpuo I & Yijihi & $1681-1696$ \\
\hline 5 & Kpaaha & Kpaaha & $1696-1706$ \\
\hline 6 & Yijisi & Yijihi & $1706-1717$ \\
\hline 7 & Jarri & Jarri & $1717-1736$ \\
\hline 8 & Joyonhi & Joyonhi & $1736-1743$ \\
\hline 9 & Saaka & Yijihi & $1743-1755$ \\
\hline 10 & Kunjokun & Jarri & $1755-1761$ \\
\hline 11 & Danduni & Jarri & $1761-1780$ \\
\hline 12 & Fijolina & Yijihi & \\
\hline
\end{tabular}




\begin{tabular}{|c|c|c|c|}
\hline 13 & Buntigsu & Yijihi & $1780-1788$ \\
\hline 14 & Sadja & Yijihi & $1788-1795$ \\
\hline 15 & Pelpuo II & Yijihi & 1795-1808 \\
\hline 16 & Jinsun & Yijihi & $1808-1823$ \\
\hline 17 & Sobuun & Yijihi & \\
\hline 18 & Bondiri & Joyonhi & $1823-1840$ \\
\hline 19 & Gangume & Yijihi & $1840-1845$ \\
\hline 20 & Bachigme & Jarri & $1845-1870$ \\
\hline 21 & Dibayiyege & Yijihi & \\
\hline 22 & Balannaya & Jarri & $1870-1870$ \\
\hline 23 & Saliya & Yijihi & \\
\hline 24 & Balannoya & Joyonhi & \\
\hline 25 & Mahama Fua & Yijihi & $1880-1888$ \\
\hline 26 & Saidu Takora I & Jarri & $1888-1897$ \\
\hline 27 & Momori Tangile & Yijihi & $1897-1908$ \\
\hline 28 & Dangana & Joyonhi & $1908-1920$ \\
\hline 29 & Pelpuo III & Yijihi & 1919-1935 \\
\hline 30 & Hamidu Bomi & Jarri & $1936-1943$ \\
\hline 31 & Sumaila & Yijihi & 1943-1949 \\
\hline 32 & Mumuni Koray & Joyonhi & 1949-1953 \\
\hline 33 & Seidu II & Yijihi & $1953-1961$ \\
\hline 34 & Sidiki Bomi & Jarri & $1961-1978$ \\
\hline 35 & Bondiri Momori II & Joyonhi & 1985-1998 \\
\hline 36 & Yakubu Soali II & Kpaaha & $2002-2006$ \\
\hline 37 & Fusieni Pelpuo IIII & Yijihi & 2007- \\
\hline
\end{tabular}

Source: Researcher's construct (2016)

The table above shows that the Yijihi gate has been the dominant gate to the position of Wa Naa . The Yijihi gate has occupied the Wa Naa position eighteen (18) times, followed by the Jarri gate nine (9) times, the Joyonhi gate six (6) times and the Kpaaha gate three (3) times. Explaining the situation, a key informant indicated that, "the Waala chieftaincy system was such that the most senior prince was often enskinned as Wa Naa and since majority of the senior (generology) princes were from the Yijihi gate, they were often enskinned as chiefs of Wa" (an interview with a key informanton $2^{\text {nd }}$ May, 2016). This corroborates Tuurey's description of the Waala chieftaincy when he posits that "the Wala chiefdom was a gerontocracy" (Tuurey, 1982:45). This has, however, given way to the rotational system.

\section{Legitimate Royal Gates of the Wa Naalung}

The issue about which gate has the legitimate right to the Wa skin is a thorny one among the key traditional players in the Waala state. The 1933 Waala constitution mentioned the descendants of three gates as those who have the right to occupy the Wa Naa's position. The gates mentioned in the document are Busa (Yijihi), Pirisi (Jarri), and Sing (Joyonhi) (Wala constitution, 1933:3). However, according to the minutes from a ruling made on the $7^{\text {th }}$ of February, 1980, by the Judicial Committee of the Upper Regional House of Chiefs, it is stated that the Jarri, Joyonhi, Kpaaha and Yijiihi are the four legitimate gates to the Wa skin (Minutes of Judiciary Committee of the Upper Regional House of Chief; cited in Bin Salih, 2009). The notion that four royal gates had the legitimate right to the Wa skin was supported by the Supreme Court of Ghana in its ruling on the $29^{\text {th }}$ of August, 1985. It named the four rightful gates to the Wa skin as Yijihi, Jarri, Joyonhi, and Kpaaha gates (Bin Salih, 2009).

It must be noted that, from the Focus Group Discussion with members of the Kpaaha gate, they were emphatic that the legitimate royal gates are four. On the other hand, members of the Yijihi, Jarri, and Joyonhi gates insist that the rightful gates to the Wa skin are three. They reiterated that members of the Naa Kpaaha gate are their patrilineal cousins and can, therefore, not occupy the Wa Naa skin. 


\section{The Perceived Causes of the Wa Chieftaincy Conflicts}

From the data collected through interviews, Focus Group Discussions, survey and secondary sources, the perceived causes of the Wa Chieftaincy conflicts are analysed below.

\subsection{Denial of the Naa Kpaaha Gate of the Right to the Wa skin}

The causes of the Wa chieftaincy conflict are varied as indicated by the data collected. From the Focus Group discussions with participants from Yijihi, Jarri and Joyonhi gates, it came out in their separate sessions that, the persistent interest to occupy the Wa Naa skin by the Naa Kpaaha gate is the main cause of the Wa chieftaincy conflict. In referring to the background behind the Kpaaha gate's exclusion, a key informant explained that "at this point, Kpaaha, a brother to Pelpuo married at an old age and it was believed that he could not impregnate a woman; yet his wife was pregnant. The woman puts to bed a baby boy and the son was regarded as not being a legitimate son (bastard). It is for this reason that the "so-called" Kpaaha gate has been denied the opportunity to occupy the Wa Naa skin" (an interview with a key informant, 2nd May, 2016).

\subsection{Exclusion of the Naa Kpaaha gate From the Waala Constitution of 1933}

On the other hand, the participants in the FGD with the Naa Kpaaha gate revealed that the Waala constitution of 1933 was responsible for eradicating the guided primogeniture system and implementing the three-gate rotational system. Consequently, only the Joyonhi, Jarri and Yijihi gates were able to assert claims to the Wa skin and were regarded the Wa Nabihi. To them, this injustice has been the main cause of the Wa chieftaincy conflict. According to a participant in the FGD with the Naa Kpaaha gate, "the Kpaaha gate has long been heavily involved in chieftaincy affairs. Not only did we own the right to the skin, but we also serve as custodians of the Nabiihi war fetish and the Wa Namine's (Wa Chiefs') burial sites. We are also entrusted with taking care of late Wa Namine's widows as well as performing the musket-firing ceremony at the funerals of late Wa Namine at the princes' residences in Fongu".

The Waala constitution was a document put together by the British Colonial Administration to streamline the chieftaincy institution of the Waala. On the $15^{\text {th }}$ July, 1933, Wa Naa Pelpuo III signed the constitution presented by the British Colonial Administration that approved the establishment of the Waala State Council. This constitution was also signed by thirteen other chiefs, namely: Nadowli Naa, Bussie Naa, Daffiama Naa, Issa Naa, Kaleo Naa, Kulbagu Naa, Funsi Naa, Kojokperi Naa, Wechiau Naa, Dorimon Naa, Sing Naa, Kperihi Naa and Busa Naa. It is this document that the Naa Kpaaha gate refers to as the cause of the persistent Wa chieftaincy conflict because the Naa Kpaaha gate was excluded from the list of the legitimate gates of the Wa royal skin. The Wa constitution of 1933 states that "we, the undersigned chiefs and councillors of the Wala State Council do hereby agree that at present there are three gates in Wala i.e. Nabisi (sons or descendants of chiefs) viz: Busa, Pirisi and Sing and that all are equal and succeed in turns to the Nalumship of Wala" (Wa Constitution,1933:3).

It is for certain that the traditional values of the Chieftaincy institution and the cultural values of the Waala people have been impinged by the British Colonial Administration's actions in various ways, not least of all through their decision to implement a rotational system that was not adopted under the traditional chieftaincy system. Given this, "a common conception is that even though the princes of Dinokpong of the Yijihi gate have not yet ascended to Wa Naa level, they could legitimately assert their right to the Naalung if the opportunity presented itself. Over the five centuries in which the Naalung has been in existence amongst the Waala people, one or more Wa Namine have emerged from the Kpaaha gate. Thus, there is an overt indication that the patrilineal Waala have always considered seniority to be the determining factor in the ascension to Naalung" (an interview with a key informant, $2^{\text {nd }}$ May, 2016).

It should be pointed out that "the Kpaaha gate's situation is not the only such example of its kind; a Wa Naa was also presented by the Yijiihi gate's Funsi Naa Jaga subsection almost five centuries after the establishment of the Waala Naalung. Nonetheless, they were excluded from ascension to the Naang based on the perception that they lacked seniority and that they had not possessed any such seniority for many generations. Eventually, seniority became irrelevant in the selection of the Wa Naa. Thus, in 1953, Wa Naa Seidu II was elected by an external electoral college and appointed to the role. This was the first time a prince from the Funsi Naa jaga was made Wa Naa" (an interview with a key informant, $2^{\text {nd }}$ May, 2016).

Other causes of the Wa chieftaincy conflicts came out from the responses from the questionnaires which were administered. Respondents were asked to state the causes of the Wa chieftaincy conflict and their responses are captured in Table 2. 
Table 2. Opinions of respondents on the cause of the Wa chieftaincy conflict

\begin{tabular}{lll}
\hline Responses & Frequency & Percentage \\
\hline Disregard for traditional succession procedures & 34 & 24.46 \\
Due to bribery and other influences & 29 & 20.86 \\
Cross-gates chieftaincy & 25 & 17.98 \\
Wrong choice of chiefs/not your turn of office & 23 & 16.54 \\
Government involvement & 13 & 9.35 \\
Involvement of Tendaana as the unilateral kingmaker & 10 & 7.19 \\
Personality of the chosen chief & 5 & 3.59 \\
\hline Total & $\mathbf{1 3 9}$ & $\mathbf{9 9 . 9 7}$
\end{tabular}

Source: Field data, 2016

From Table 2, it was realised that $24.46 \%$ of the respondents mentioned disregard for traditional succession procedures as the cause of the Wa chieftaincy conflict. This finding reveals a mere neglect of existing succession procedures and contrary to report by the United Nations (2007) reports that traditional indigenous approaches carry the potential for greater efficiency because they are tailored to each party's needs. About $20.86 \%$ of the respondents said bribery and other influences was the cause of the Wa chieftaincy conflict. Another $17.9 \%$ of the respondents mentioned the deliberate attempt of some of the gates to cross or side-step the other as the cause of the Wa chieftaincy conflict while $16.54 \%$ of the respondents stated that when the wrong person is chosen as the Wa Naa, it serves as a cause of the Wa chieftaincy conflict to reoccur. Also, 9.35 percent of the respondents stated that the involvement of the Government in the affairs of the chieftaincy institution is the cause of the Wa chieftaincy conflict while 7.19 percent of the respondents revealed that the involvement of the Tendaana of Wa as the unilateral kingmaker of the Waala kingdom is the cause of the Wa chieftaincy conflict. About 3.59 percent of the respondents indicated that the personality of the person chosen as chief is the cause of the Wa chieftaincy conflict.

\subsection{Persistence of the Wa Chieftaincy Conflict}

The opinions of respondents were sought regarding what accounts for the persistence of the Wa chieftaincy conflict. Respondents mentioned a lot of factors that account for the persistence of the Wa chieftaincy conflict. The figures in Table 3 show the percentage of respondent's views in descending order.

Table 3. Respondents views on what accounts for the persistence of the Wa chieftaincy conflict

\begin{tabular}{|c|c|c|}
\hline Response & Frequency & Percentage \\
\hline Denial of succession rights to one of the gates & 33 & 23.74 \\
\hline Lack of documented history on succession plan & 27 & 19.42 \\
\hline $\begin{array}{l}\text { People do not want to follow the traditional path to } \\
\text { become chiefs any longer }\end{array}$ & 25 & 17.98 \\
\hline Conflicts as a form of business to some people & 22 & 15.82 \\
\hline Lack of understanding among the princes & 16 & 11.51 \\
\hline Truth, a scarce commodity in the chieftaincy institution & 11 & 7.91 \\
\hline Choice of person as chief & 5 & 3.59 \\
\hline Total & 139 & 99.97 \\
\hline
\end{tabular}

Source: Field data, 2016

From Table 3, it was realised that $23.74 \%$ of respondents mentioned that the denial of succession rights to one of the chieftaincy gates accounts for the persistence of the Wa chieftaincy conflict. Differences between factions might account for this. As Deutsch (1991:30) states that "it is incompatible differences which give rise to conflict. Hence, it is not the objective incompatibility that is crucial, but rather the perceived incompatibility". About $19.42 \%$ of respondents mentioned the lack of documentation of a succession plan of the Wa skin as what accounts for the persistence of the Wa chieftaincy conflict while $17.98 \%$ of respondents revealed that people do not want to follow the traditional path to ascend to the Wa skin; hence, it accounts for the persistence of the Wa chieftaincy conflict. Also, $15.82 \%$ of respondents stated that some people use the Wa chieftaincy conflict as a form of business, 
therefore, it accounts for the persistence of the Wa chieftaincy conflict while $11.51 \%$ of respondents percent mentioned the lack of understanding among the Waala princes as the cause of the persistence of the Wa chieftaincy conflict. About 7.91 percent of respondents said the absence of truth in matters relating to the chieftaincy institution in $\mathrm{Wa}$ is the cause of the persistence of the Wa chieftaincy conflict while 3.59 percent of respondents mentioned that the choice of a 'wrong' person as Wa Naa accounts for the persistence of the Wa chieftaincy conflict. A respondent remarked that "the Wa chieftaincy conflict shall persist until all the necessary and appropriate traditional norms are respected and followed". Contrary to Freud's (cited in Bloomfield \& Moulton, 1997) position that engagement in conflict is a genetically inevitable behaviour and that, it is not possible to suppress humanity's aggressive tendencies, these findings reveal key factors that account for the persistence of the conflict and not behavioural tendencies.

\section{Recommendations}

The Waala Traditional Council and the Upper West Regional Regional House of Chiefs should facilitate an effective link and collaboration between the various royal gates to the Wa skin. It is essential that the reports of such collaboration be regularly sent out to the followers of the various royal gates. It is important that the leaders and followers of the various royal gates should be involved in the formulation of rules and regulations by signing a social contract spelling out infractions and sanctions.

\section{References}

Assimeng, M. (1999). Social structure of Ghana, a study in persistence and change. Tema: Ghana Publishing Corporation.

Bin Salih, M. (2001). A History of Waala, the Ahmadiyya Factor. Accra: Salihsons.

Bin Salih, M. (2009). The Kingdom of Wa: Elucidation of Our Origins and Settlement. Accra: Salihsons.

Bloomfield, L. P., \& Moulton, A. (1997). Managing International Conflict. New York: NY: St. Martin's Press, Inc.

Daanaa, H. S. (1992). The impact of state law on custom and leadership in a post-colonial state: A legal historical case study of centralized Wa and Acephalous Chakali in Northern Ghana. Unpublished Ph.D Thesis, London.

Dougah, J. C. (1966). Wa and Its People. Institute of African Studies, Legon.

Nabila, J. S. (2006). Decentralisation within the Traditional System of Authority in Ghana. Paper Presented at a KAF/NHC Organised Workshop for Traditional Leaders and District Chief Executives held in Akosombo from 16th - 18th August, 2006.

Tuurey, G. (1982). An introduction to the Mole-speaking community. Wa: Ghana Education Service.

Wilks, I. (1982). Wangara, Akan and Portuguese in the fifteenth and sixteenth centuries. I. The matterof Bitu. The Journal of African History,23(3), 333-349.

Wilks, I. (1989). Wa and the Wala-Islam and Polity in Northern Ghana. Cambridge: Cambridge University Press.

\section{Copyrights}

Copyright for this article is retained by the author(s), with first publication rights granted to the journal.

This is an open-access article distributed under the terms and conditions of the Creative Commons Attribution license (http://creativecommons.org/licenses/by/4.0/). 